\title{
ENGAGEMENT IN DISTANCE EDUCATION SETTINGS: A TREND ANALYSIS
}

\author{
Ayse BAGRIACIK YILMAZ \\ ORCID: 0000-0002-9971-2440 \\ Department of Computer Education and Instructional Technologies \\ Aydin Adnan Menderes University \\ Aydin, TURKEY \\ Dr. Phil BANYARD \\ ORCID: 0000-0003-2527-0755 \\ School of Social Sciences \\ Nottingham Trent University \\ Nottingham, UK
}

Received: 18/10/2018 Accepted: 18/02/2019

\begin{abstract}
This study examined studies focusing on student engagement in distance education using a trend analysis technique. 154 studies published in web of science database were included in the study. Analysis showed that there is an increasing effort to understand student engagement. Researchers are mostly focusing on instructional design and educational technology. More effort is needed in the area of distance education systems and theories. The findings offer support for Chickering and Gamson's Seven Principles of Good Practice as important in promoting student engagement in distance education. However, six new components were added to these principles: media properties, student characteristics, teaching method, course/content design, innovative techniques, and instructor competencies.
\end{abstract}

Keywords: Student engagement, online education, distance education, seven principles of good practice, systematic review.

\section{INTRODUCTION}

Distance education, which has started its journey as correspondence learning, now has a variety of forms such as web based, online, blended, ubiquitous, mobile and e-learning, and all these terms are used interchangeably (Karatas, Bagriacik-Yilmaz, Dikmen, Ermis, \& Gurbuz, 2017). Regardless of how it is named, distance education has become an essential component of higher education (Bernat \& Frailing, 2015; Toven-Lindsey, Rhoads, \& Lozano, 2015). It is recognized in the literature that distance education has many opportunities and benefits. However, it is still necessary to question the quality of distance education to provide better learning experiences, and student engagement is one of the issues that needs to be questioned (Chen, Gonyea \& Kuh, 2009).

Student engagement is considered as an important component of learning environments and an important predictor of student retentions and success (Chen et al., 2008; Chickering \& Gamson, 1987; Kuh, 2009; Herrington, Oliver, \& Reeves, 2003; Pascarella \& Terenzini, 2005). Engaging students is a challenging task both in face-to-face and distance education settings. Because the students are physically separated from the other students and instructor in distance education, it becomes more difficult to engage students (Bolliger \& Halupa, 2018; Moore, Utschig et al., 2008). Currently, the studies focused on the factors that influence student engagement and the strategies to ensure student engagement in online learning/distance education are increasing (Ma, Han, Yang, \& Cheng, 2015; Martin \& Bolliger, 2018).

Student engagement is defined as "the time and energy students devote to educationally sound activities inside and outside of the classroom, and the policies and practices that institutions use to induce students to take part in these activities" (Kuh, 2003). Similarly, according to the definition of the National Survey of Student Engagement $\left(\mathrm{NSSE}^{\bullet}\right.$, 2017) engagement is related to the amount of time and effort students 
committed to their studies and educational activities, and institutions' effort to get students to participate in learning activities. Engagement was also considered as the frequency with which students participate in learning activities (Smith, Sheppard, Johnson, \& Johnson, 2005).

In the framework for student engagement named seven principles (SP) for good practice in undergraduate education, Chickering and Gamson (1987) stated that good college education should provide (1) studentfaculty interaction, (2) student collaboration, (3) active learning, (4) prompt feedback, (5) time on task, (6) high expectations, and (7) respect for diverse talents and ways of learning. While this framework was created for face-to-face learning environments, in a follow-up study Chickering and Ehrmann (1996) argued how these principles are related to technology-enhanced learning environments. Furthermore, there are studies evaluating web-based distance learning environments (Graham, Cagiltay, Craner, Lim, \& Duffy, 2000) or students' perspectives about virtual classrooms (Cakiroglu, 2014) based on these principles. These principles are used as a base for the National Survey of Student Engagement (NSSE), used to measure participation in Canada and the United States (NSSE, 2017).

In the literature there are two theories that refer to engagement, the Theory of Engagement (Shneiderman, Alavi, Norman, \& Borkowski, 1995), and Flow Theory (Csikszentmihalyi 1997). The balance between the degree of skill and the degree of challenge is the basis of Flow Theory. The flow experience occurs if the challenge level is neither too much higher nor too much lower than one's skill level. If this balance is not provided, one can experience apathy, anxiety or relaxation (Csikszentmihalyi 1997). Shernoff, Csikszentmihalyi, Schneider and Shernoff (2003) suggest that the learning activities should be challenging and relevant, however they should allow learners to feel confident in their ability and control in their learning environment.

Engagement Theory is a conceptual framework for technology-based learning and teaching. It was based on Kearsley and Shneiderman's experiences. In this theory, it is emphasized that to increase engagement in learning environments, meaningful interaction with other students and worthwhile tasks are essential. The theory has three basic principles, relate, create and donate. The first principle is related to team efforts and collaboration which is also emphasized in SP (Chickering \& Gamson, 1987). Second, one aims to make learning a creative and purposeful activity. The precious contributions made while learning help students to engage and this is the logic of the donate principle. This principle can be supported by authentic learning contexts (Kearsley \& Shneiderman, 1998).

Although no one of the frameworks or theories mention any types of engagement, it is possible to see a considerable number of studies (Hew, Huang, Chu, \& Chiu, 2016; Northey, Bucic, Chylinski, \& Govind, 2015; Pellas, 2014, Sun \& Rueda, 2012) conducted based on the engagement types identified by Fredricks, Blumenfeld and Paris (2004). Engagement was considered as a multifaceted concept by the researchers. They have identified three types of engagement, behavioral, emotional and cognitive based on the previous studies on engagement. It is stressed that these engagement types are not isolated but interrelated concepts. Behavioral engagement is related to participating in academic and social/extracurricular activities while emotional engagement is about the positive and negative reactions to instructors, other students, academics and school. Cognitive engagement refers to the student's thoughtfulness and willingness to complete learning tasks (Fredricks et al., 2004).

As previously mentioned, engagement is an important concept both for face-to-face and distance education settings. Accordingly the number of the studies on student engagement in distance education settings is dramatically increasing. For instance, in Web of Science database while the number of articles which include the words distance education (and types of distance education), engagement and student/learner in its topic was 33 in 2011, it has increased to 135 in 2016. When it is considered the student dropout or attrition rates are higher in distance education than traditional education (Boston, Ice \& Gibson, 2011; Boyle, Kwon, Ross \& Simpson, 2010; Cochran, Campbell, Baker \& Leeds, 2014; Simpson, 2013) and engagement is a key for the retention, it is not surprising that the number of studies about student engagement is increasing.

Today, it is almost impossible to imagine a distance education system without an online component. And online learning has both opportunities and challenges to promote engagement (Tomas, Lasen, Field \& Skamp, 2015). In online learning, students often need to be self-directed and engaged in their learning because they had no enough reinforcement and prompts from their instructor and the other students (Delen, Liew \& Wilson, 2014). Student engagement and the effects of teachers' behaviors on engagement are issues that attracts researchers' attention (Ma et al., 2015). 
There is a growing body of research on engagement in distance education settings. Researchers are trying to find out the ways to increase engagement in these learning environments. Besides, there is a significant effort to determine the factors affecting student engagement. For instance, Carpenter, Reddix and Martin (2016) have examined the effects of Web 2.0 tools usage in blended education on students' engagement and retention, and have reached positive results in terms of increasing engagement. Positive findings have also been reached in the studies using some specific Web 2.0 tools such as Wiki (Neumann \& Hood, 2009; Snodgrass, 2011), Facebook (Maisonneuve, Chambe, Lorenzo, \& Pelaccia, 2015; Northey et al., 2015), and podcast-vodcast (van Oordt \& Mulder, 2016).

In a study conducted by Matthews, Adrews and Adams (2011) to examine the role of social learning spaces on the student engagement, it was found that these spaces can contribute to enhance student engagement in blended learning environments. Similarly, Thoms and Eryilmaz (2014) compared the effects of online social network (OSN) and learning management system (LMS) on students' opinions, and at the end of the study students stated that OSN provides higher engagement than LMS.

It is possible to see some conflicting results in the literature. For instance, Park et al. (2015) found that whether the instructor is in the online discussion forum doesn't affect student engagement. While the importance of encouragement by the instructor (Kuiper, Solomonides, \& Hardy, 2015), instructor's course preparation, guidance, assistance ( $\mathrm{Ma}$ et al., 2015), and online participation and e-moderating skills (Armellini \& Aiyegbayo, 2010) were emphasized as important components to promote student engagement. Acoording to a very recent study (Martin \& Bolliger, 2018) learner-instructor engagement strategies were the most valuable one. Another contradiction can be seen in studies on discussion boards. In a study conducted by Fukuzava and Boyd (2016), it was stated that the discussion board had no effect on the engagement, however the positive effects of discussion boards on engagement were stressed in some studies (Sutherland, Howard, \& Markauskaite, 2010; Mehvar, 2010; Xie, 2013).

Engagement has been found to be related to or supported by various variables in the literature such as selfefficacy (Prior, Mazanov, Meacheam, Heaslip, \& Hanson, 2016), tutoring styles (Chae \& Shin, 2016), gamification (Hew, Huang, Chu, \& Chiu, Tan \& Hew, 2016), affect sensitive intelligent systems (Chen, Luo, Liu, Liu, Zhang, \& Kolodziej, 2016), adaptive learning systems (Brinton, Rill, Ha, Chiang, Smith, \& Ju, 2015), peer evaluation (Adwan, 2016), team based learning (Tsai, 2015), flexible flipped learning (Wanner \& Palmer, 2015), self-determined learning (George-Walker \& Keeffe, 2010), self-regulated learning (Conway, Johnson, \& Ripley, 2010), problem based learning (Stebbings, Bagheri, Perrie, \& Blyth, 2012), role play activities in virtual reality settings (Gregory \& Masters, 2012), and blended learning (Lee, 2016; Leslie, Beverley, \& Sian, 2015; Protsiv, Rosales-Klintz, Bwanga, Zwarenstein, \& Atkin).

As it can be seen, engagement has a complex structure and different studies reach different results about engagement. At this point, reviewing all these results from a holistic point of view will be helpful in understanding the concept of student engagement in depth. Such a review is important in terms of determining the trend of studies on student engagement. In this regard, the aim of this study is to examine the research studies conducted between 1970 and 2016 on student engagement in distance education settings. In accordance with this aim the following research questions were considered:

1. What is the distribution of studies concerning engagement in distance education according to the year of publication?

2. Which countries are the major contributors of the filed?

3. What is the situation of authors' collaboration in the field?

4. What is the distribution of studies according to disciplines?

5. What is the distribution of studies according to research areas?

6. What are the sample sizes of the studies?

7. Which research models are used?

8. Which data collection tools are used?

9. Which variables are influencing or related to engagement in distance education settings?

10. Which theories are used to ground the studies?

11. Which technologies are used? 


\section{METHOD}

\section{Research Design}

The aim of this study is to systematically examine the studies on engagement in distance education. This review is based on trend analysis technique. Trend analysis was based on descriptive analysis, one of the qualitative research methods. In the descriptive analysis technique, data are organized and interpreted according to previously devised categories (Yildirim \& Simsek, 2013). In this study, an evaluation form created by the researchers was used.

It is necessary to use inclusion and excluding criteria in order to select appropriate publications for the purpose of research when it is considered engagement has a popular and long history. The Web of Science database has been included in the review because it has high quality publications (Hung \& Zhang, 2012). One of the reasons for the selection of this database is that it contains many well-known and leading magazines in the field of distance education (Zawacki \& Richter, 2009) such as Open Learning (OL), Distance Education (DE), the American Journal of Distance Education (AJDE), the Journal of Distance Education (JDE), and the International Review of Research in Open and Distance Learning (IRRODL).

The search was based on the specified words, "distance education" or "distance learning" or "blended learning" or "blended education" or "mobile learning" or "mobile education" or "m-learning" or "e-learning" or "online learning" or "online education" or "ubiqitous learning" AND "engagement" or "engage" or "engaging" or "engaged" AND "student" or "learner". In addition to the search words, criteria such as to be written in English, to be full text (not only abstract), and to be article (not proceedings, reports, thesis or books) were used.

At the end of this search 553 articles have been reached. 22 articles can not be included in the study because they were not accessible from both researchers university database. Since only the Web of Science database is used, the number of duplicate articles is very small. After removing 22 inaccessible and 4 duplicate articles, a total of 527 articles remained. These 513 articles were examined based on inclusion and exclusion criteria which are explained below. Finally, 154 articles were remained after applying the criteria. The distribution of the articles by journals was given in Table 1 .

Table 1. Distribution of the studies by journals

\begin{tabular}{llc}
\hline Journals & $f$ & $\%$ \\
\hline Computers \& Education & 11 & 7.14 \\
Australasian Journal of Educational Technology & 10 & 6.49 \\
IRRODL & 8 & 5.19 \\
Internet and Higher Education & 7 & 4.55 \\
Computers in Human Behavior & 6 & 3.90 \\
Distance Education & 6 & 3.90 \\
American Journal of Pharmaceutical Education & 6 & 3.90 \\
BMC Medical Education & 5 & 3.25 \\
British Journal of Educational Technology & 5 & 3.25 \\
Journal of Computer Assisted Learning & 5 & 3.25 \\
Anatomical Sciences Education & 4 & 2.60 \\
Higher Education Research \& Development & 4 & 2.60 \\
Educational Technology \& Society & 3 & 1.95 \\
IEEE Transactions on Learning Technologies & 3 & 1.95 \\
Journal Of Geography in Higher Education & 3 \\
Educational Technology Research and Development & 3 & 1.95 \\
Interactive Learning Environments & 2 & 1.30 \\
New Review of Hypermedia and Multimedia & 2 & 1.30 \\
Nurse Education in Practice & 2 & 1.30 \\
Other & 2 & 1.30
\end{tabular}




\section{Data Collection Inclusion and Exclusion Criteria}

The articles to be included in the review were selected according to the specific inclusion and exclusion criteria. In order to be included in the study, the article must have reached a conclusion about the factors that affect or relate to engagement. Since the focus of this research is distance learning, studies that focus only on the use of a particular software for a short time in the class are not included in the research. In addition, literature review studies and the studies which made general interpretations only based on assumptions are also excluded.

\section{Reliability}

In order to ensure the reliability of the articles to be included in the review, 20 articles selected randomly from all the articles were examined by the two researchers according to the inclusion / exclusion criteria and disputes were resolved by discussing them. In addition, 20 randomly selected articles are coded by two encoders according to the evaluation form in order to ensure intercoder reliability. Cohen's Kappa coefficient is used for intercoder reliability. Cohen's Kappa was calculated as 0.67 in the first step. The two encoders then discussed and agreed on the differences and Cohen's Kappa was set to 0.84 in the second calculation. 0.75 and above indicates that the reliability between the encoders is excellent (Landis \& Koch, 1977).

\section{Classifications}

\section{Classification of Discipline}

Subject disciplines were classified by using the classification method developed by Wu, Wu, Chen, Kao, Lin, and Huang (2012). Table 2 shows the classification of disciplines established by Wu et al. (2012), based on the studies of Franklin (1999) and Wanner, Lewis and Gregorio (1981).

Table 2. Disciplines and sub-disciplines used as a base in the classification of discipline

\begin{tabular}{ll}
\hline Discipline & Sub-Discipline \\
\hline Human Sciences & History, languages and linguistics, literature, performing arts, philosophy, religion, visual arts \\
Social Sciences & $\begin{array}{l}\text { Anthropology, archaeology, area/regional studies, cultural and ethnic studies, economics, social } \\
\text { studies, gender and sexuality studies, geography, politics, psychology and sociology }\end{array}$ \\
Natural Sciences & $\begin{array}{l}\text { Space sciences, earth sciences, life sciences, chemistry, physics } \\
\text { Formal Sciences }\end{array}$ \\
$\begin{array}{l}\text { Computer sciences, logic, maths, statistics and system sciences } \\
\text { Professional and } \\
\text { Applied Sciences }\end{array}$ & $\begin{array}{l}\text { Agriculture, architecture and design, business studies, theology, education, engineering, } \\
\text { physical performance and recreation studies, journalism, media studies and communication, } \\
\text { law, library and museum studies, military sciences, public administration, social service and } \\
\text { transportation }\end{array}$ \\
\hline
\end{tabular}

\section{Classification of Method}

The method classification was made by using a form created by Goktas et al. (2012). This classification framework was selected because it is detailed and clear. In this classification, methods are divided into four categories as quantitative, qualitative, mixed method similar to Creswell's (2013) classification and literature review. Quantitative studies are separated into two sections as experimental (fully experimental, quasiexperimental, and weakly experimental and single-subject) and non-experimental (descriptive, comparative, correlational, screening, ex post facto, and secondary data analysis). Qualitative studies include culture analysis, case studies, grounded theory, critical study, case study, historical analysis and conceptual analysis. Mixed studies are separated into three sections as explanatory, exploratory and triangulation studies. The final category -literature reviews- involve meta-analysis and literature review. In the current study authors have added action research and design based research to the qualitative studies. 


\section{Classification of Research Areas}

In the study, the classification of research area was made by using a classification system developed by Zawacki \& Richter (2009). In this classification there are 15 research areas which were organized into 3 broad categories. The main categories are macro level (Distance education systems and theories), meso level (Management, organization, and technology), and micro level (Teaching and learning in distance education). Macro level includes sub-categories named (1) access, equity, and ethics, (2) globalization of education and cross-cultural aspects, (3) distance teaching systems and institutions, (4) theories and models, and (5) Research methods in distance education and knowledge transfer. Meso level has seven sub-categories named (1) management and organization, (2) costs and benefits, (3) educational technology (4) innovation and change, (5) professional development and faculty support, (6) learner support services, and (7) quality assurance. Last category, micro level consists of (1) instructional design, (2) interaction and communication in learning communities, and (3) learner characteristics sub-categories.

\section{FINDINGS}

\section{Distribution of Studies by the Year of Publication}

In Web of Science database, the first study on student engagement in distance education was published in 1994. However, the first study that meets the inclusion and exclusion criteria of the current study was found in 2000 .

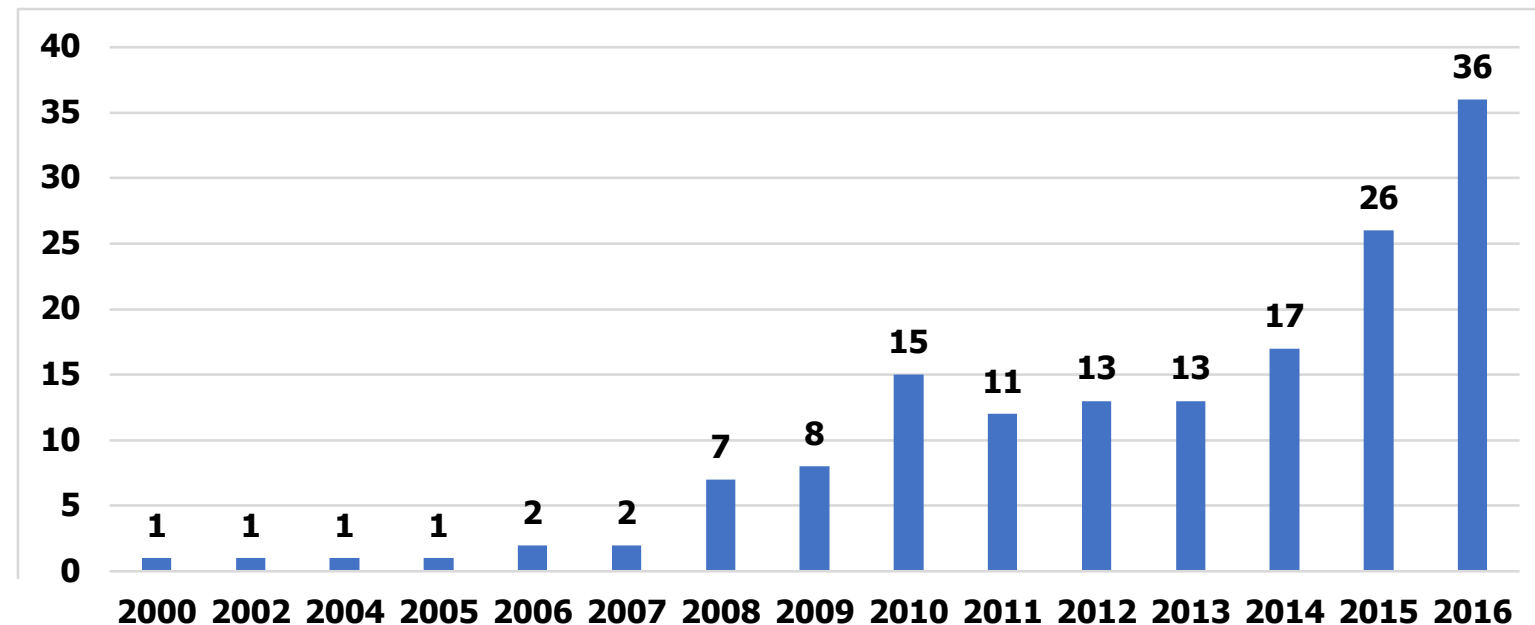

Figure 1. Distribution by the year of publication

The number of studies have increased steadily since 2000 (Figure 1). There is a growing effort to determine the factors influencing or related to student engagement in distance education. It may related to the fact that engagement is an important variable to promote student retention in distance education (Tower, Walker, Wilson, Watson, \& Tronoff, 2015), and distance education has become an essential component for the institutions (Bernat \& Frailing, 2015; Toven-Lindsey, Rhoads, \& Lozano, 2015).

\section{Major Contributor Countries of the Field}

Figures 2 and 3 present the major contributor countries of the field. The countries have less than 2 articles are gathered under the "other" category. 


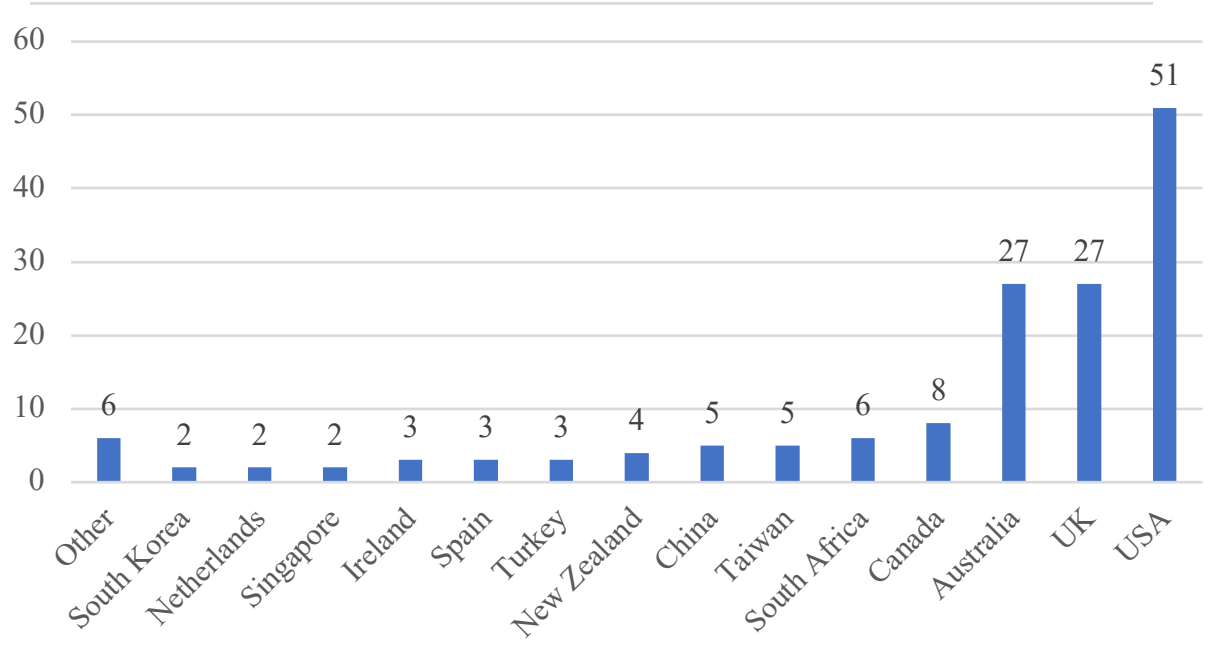

Figure 2. Publication frequencies based on first authors' country

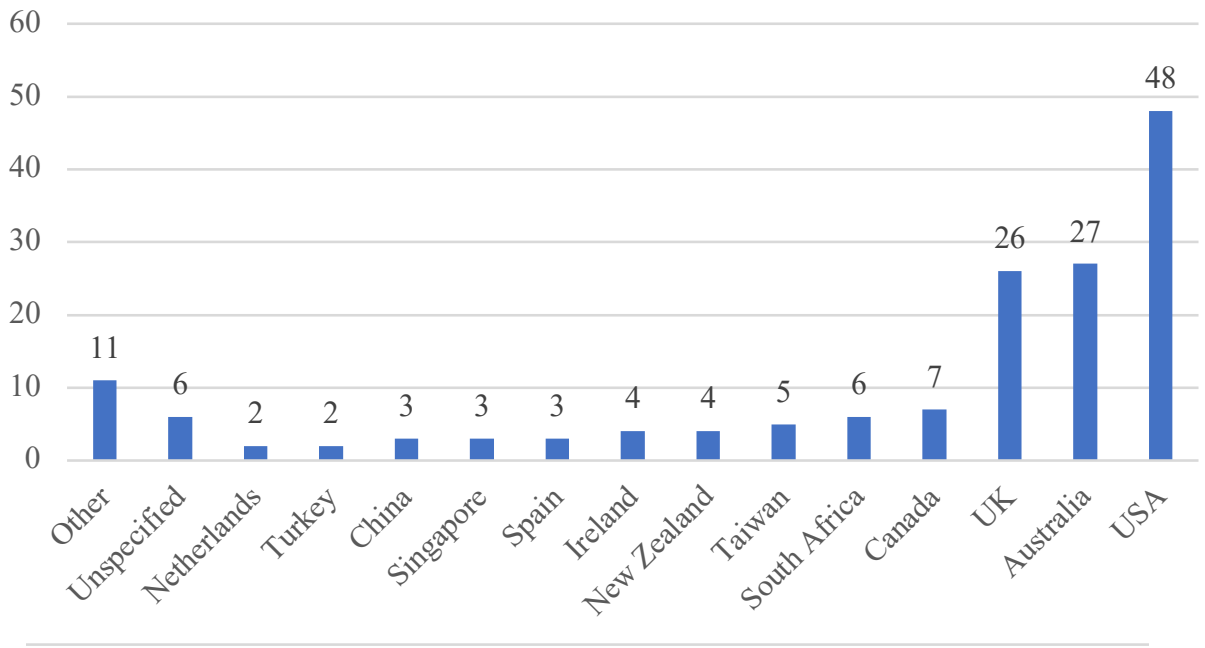

Figure 3. Publication frequencies based on intervention country

The USA, UK and Australia are the major contributor countries (Figures 2 and 3). Similarly Karatas, Bagriacik Yilmaz, Dikmen, Ermis and Gurbuz (2017) have found that the USA, UK, Taiwan, and Australia are the major contributors. Furthermore these countries were determined as major contributors in mobile, ubiquitous and synchronous online learning studies (Hwang \& Tsai, 2011; Hung \& Zhang, 2012, Martin, Ahlgrim-Delzell, \& Budhrani, 2017). It is surprising that Taiwan which is usually among the first three countries in distance studies ranks 6 th. Another conspicuous point is that Turkey that has a distance megauniversity (Anadolu University, 2017) has not shown the expected contribution.

\section{Authors' Collaboration Tendencies}

The number of multiple-author studies are well ahead of the single author studies (Figure 4). The authors prefer to work in collaboration with their colleagues. Similar results were reached by Zawacki-Richter et al. (2009), Zawacki-Richter and von Prummer (2010), and Karatas et al. (2017). Zawacki-Richter et al. (2009) have found that the collaboration tendencies of the authors are increasing by years and they related this situation with emerging communication technologies. The collaboration between the authors may help to enrich the body of knowledge in the field. Besides, it is beneficial for the authors in terms of providing high impact publications (Costas \& van Bocheve, 2012). 


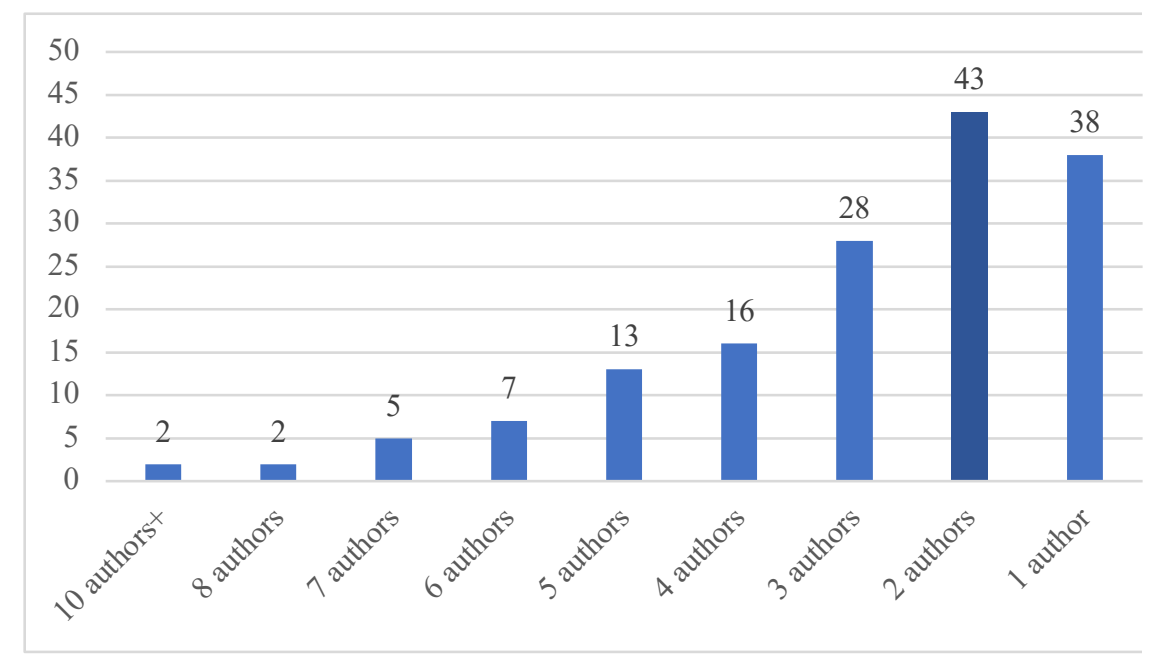

Figure 4. Number of authors in the studies

\section{Distribution of Studies According to Disciplines}

The disciplines were determined based on program that students are studying. Studies mostly focus on professional and applied sciences discipline $(53.16 \%)$, followed by social sciences $(8.42 \%)$, and formal sciences $(6.84 \%)$ (see Table 3).

Table 3. Distribution of the studies according to disciplines

\begin{tabular}{llll}
\hline Disciplines & Sub disciplines ( $f$ ) & Total $f$ & $\%$ \\
\hline \multirow{2}{*}{$\begin{array}{l}\text { Professional and } \\
\text { Applied Sciences }\end{array}$} & $\begin{array}{l}\text { Health sciences (44), Education (22), Business studies (14), Engineering } \\
\text { (11), Media studies and communication (3), Human physical performance } \\
\text { and recreation studies (2), Library and museum studies (2), Journalism (1), }\end{array}$ & 101 & 53.16 \\
& Agriculture (1), Law (1) & & \\
Social sciences & Social sciences (3), Economics (3), Anthropology (1) & 16 & 8.42 \\
Formal Sciences & Psychology and sociology (8), Geography (1) & & 6.84 \\
Human sciences & Computer sciences (8), System sciences (2), Logic (1), Maths (1), Statistics (1) & 13 & \\
Natural Sciences & Performing arts (3), Languages and linguistics (2), Philosophy (1), Religion & 8 & 4.21 \\
Unspecified & Life sciences (4), Earth sciences (2), Chemistry (1) & 7 & 3.68 \\
Non-specified & The studies that haven't stated the discipline even though they could state. & 32 & 16.84 \\
\hline
\end{tabular}

Considering sub-disciplines, it can be said that studies mostly conducted in health sciences context $(\mathrm{f}=44)$. Our findings support the study results conducted by Wu et al. (2012) in terms of discipline. However, they have reached different results in terms of sub-disciplines as the highest frequency belonged to languages and linguistics in their study. Health sciences was the second most studied sub-discipline in Karatas et al.'s (2017) study. At this point it is necessary to say it was expected that education would be the first sub-discipline because the theme of the research is "distance education".

\section{Distribution of Studies According to Research Areas}

A categorization was performed based on the framework created by Zawacki-Richter et al. (2009). The majority of articles focused on issues that refer to the micro perspective (49.47\%). The most studied areas are instructional design (39.21\%), educational technology (31.32\%), distance teaching systems and institutions $(8.42 \%)$, and interaction and communication in learning communities $(5.53 \%)$ (see Table 4). 
Table 4. Distribution of studies according to research areas

\begin{tabular}{|c|c|c|c|c|c|}
\hline Research areas & Sub research areas & $f$ & $\%$ & Total $f$ & Total \% \\
\hline \multirow{5}{*}{$\begin{array}{l}\text { Macro level: Distance } \\
\text { education systems and } \\
\text { theories }\end{array}$} & Distance teaching systems and institutions & 32 & 8.42 & \multirow{5}{*}{41} & \multirow{5}{*}{10.79} \\
\hline & Theories and models & 9 & 2.37 & & \\
\hline & Access, equity, and ethics & 0 & 0 & & \\
\hline & Globalization of education and cross-cultural aspects & 0 & 0 & & \\
\hline & $\begin{array}{l}\text { Research methods in distance education and } \\
\text { knowledge transfer }\end{array}$ & 0 & 0 & & \\
\hline \multirow{7}{*}{$\begin{array}{l}\text { Meso level: Management, } \\
\text { organization, and } \\
\text { technology }\end{array}$} & Educational technology & 119 & 31.32 & \multirow{7}{*}{151} & \multirow{7}{*}{39.74} \\
\hline & Innovation and change & 10 & 2.63 & & \\
\hline & Professional development and faculty support & 8 & 2.11 & & \\
\hline & Quality assurance & 8 & 2.11 & & \\
\hline & Learner support services & 3 & 0.79 & & \\
\hline & Management and organization & 2 & 0.53 & & \\
\hline & Costs and benefits & 1 & 0.26 & & \\
\hline \multirow{3}{*}{$\begin{array}{l}\text { Micro level: Teaching } \\
\text { and learning in distance } \\
\text { education }\end{array}$} & Instructional design & 149 & 39.21 & \multirow{3}{*}{188} & \multirow{3}{*}{49.47} \\
\hline & $\begin{array}{l}\text { Interaction and communication in learning } \\
\text { communities }\end{array}$ & 21 & 5.53 & & \\
\hline & Learner characteristics & 18 & 4.74 & & \\
\hline
\end{tabular}

When it is considered that the educational technology area was ranked fifth in Zawacki-Richter et al.'s (2009) study, it can be said that educational technology has gained popularity. Similar results were also reached in a study examining research trends in Turkish distance education (Bozkurt, Kumtepe, Kumtepe, Aydin, Bozkaya, \& Aydin, 2015). Examining the table it can be clearly said that the distance education studies need to consider the macro level areas.

\section{Sample Sizes of the Studies}

The percentages of the studies with sample sizes 1-30 (24\%), 31-100 (29\%) and 101-300 (25\%) are quite close (Figure 5). Although they have divided the groups in different ranges Martin et al. (2017) has found that sample sizes between 1-100 are the most commonly used. However, in the current study the biggest pie belongs to the studies with the sample size 31-100 (29\%) which is similar to the results of the study conducted by Karatas et al. (2017). Kilic-Cakmak et al. (2015) also found that this sample size is the most used one in educational technology studies published in 2013. This situation may be due to the fact that these samples are more available to researchers.

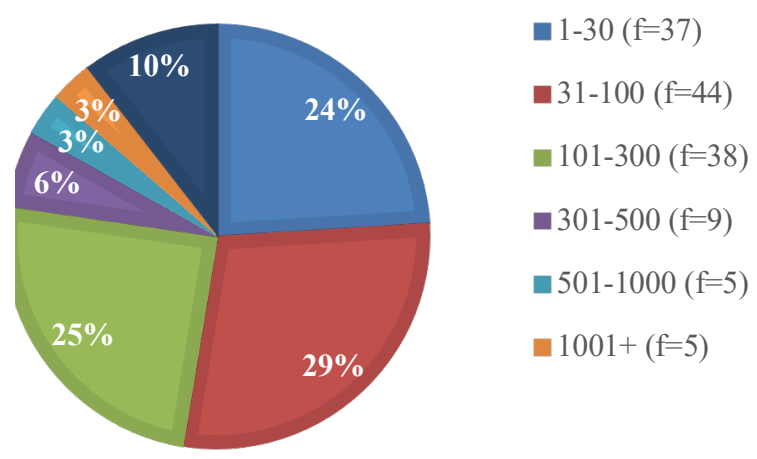

Figure 5. Distribution of the sample sizes 


\section{Research Methods and Patterns Used in the Studies}

The field is dominated by the quantitative studies (49.70\%) (see table 5 and figure 6). Similar result were reached by Zawacki-Richter et al. (2009) in distance settings. More specifically Karatas et al. (2017) determined quantitative methods as the most commonly used ones in distance education considering interaction. The same result was reached by Bozkurt et al. (2015) examining distance education dissertations in Turkey.

Table 5. Distribution of research methods and designs utilized in the studies

\begin{tabular}{|c|c|c|c|c|}
\hline Research methods & Research designs & $f$ & Total $f$ & $\%$ \\
\hline \multirow{9}{*}{ Quantitative } & Weakly experimental & 53 & \multirow{9}{*}{75} & \multirow{9}{*}{49.70} \\
\hline & Correlational & 10 & & \\
\hline & Fully experimental & 4 & & \\
\hline & Descriptive & 2 & & \\
\hline & Ex post facto & 2 & & \\
\hline & Quasi experimental & 1 & & \\
\hline & Comparative & 1 & & \\
\hline & Secondary data analysis & 1 & & \\
\hline & Learning analytics & 1 & & \\
\hline \multirow{2}{*}{ Mixed } & Triangulation & 56 & \multirow{2}{*}{57} & \multirow{2}{*}{38.01} \\
\hline & Explanatory & 1 & & \\
\hline \multirow{3}{*}{ Qualitative } & Case study & 16 & \multirow{3}{*}{21} & \multirow{3}{*}{13.64} \\
\hline & Design based research & 3 & & \\
\hline & Action research & 2 & & \\
\hline Literature review & Meta-analysis & 1 & 1 & 0.65 \\
\hline
\end{tabular}

It is obvious that the mixed method studies $(38.01 \%)$ and qualitative studies have increased over the years (Figure 6). In support of this finding, qualitative designs were found as the most used ones in synchronous online learning (Martin et al., 2017). It is surprising that triangulation is the most preferred research pattern. It can be said that the researchers are collecting both qualitative and quantitative date in order to get deeper information about distance education.

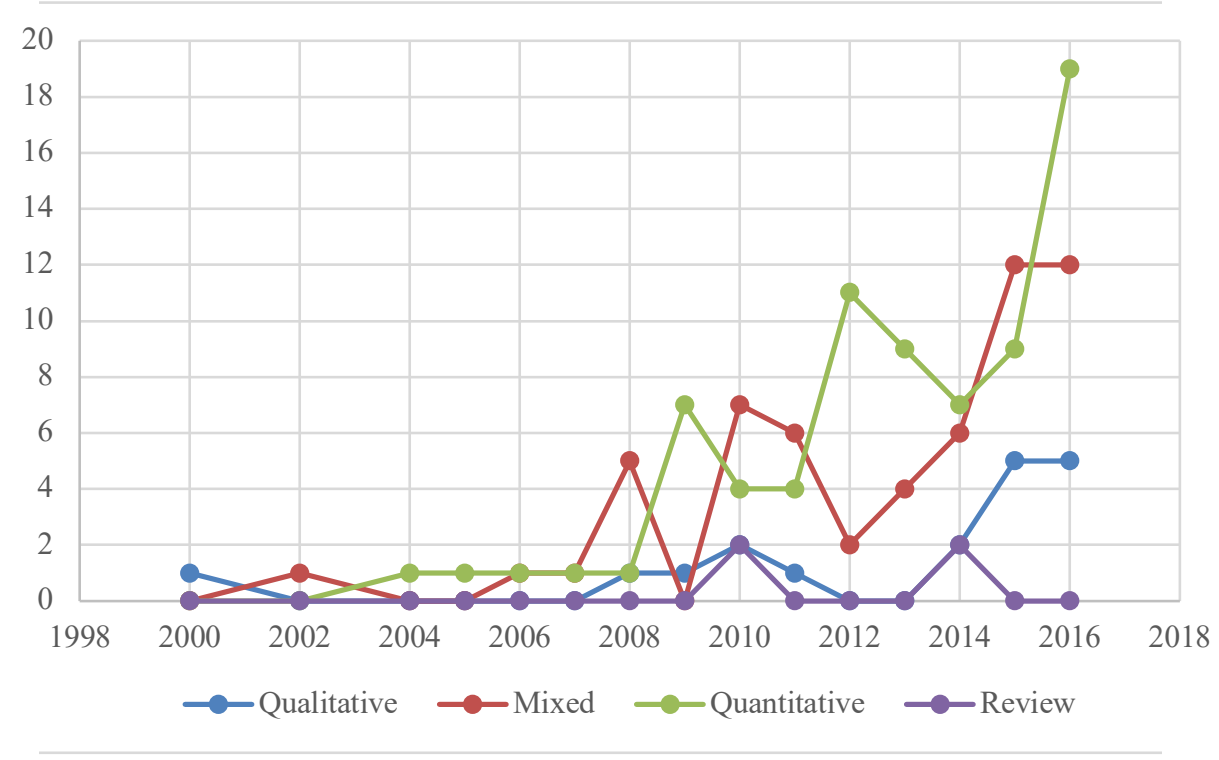

Figure 6. Distribution of the research methods by years 


\section{Research Methods and Patterns Used in the Studies}

Table 6. Types and distribution of data collection tools used in the studies

\begin{tabular}{lll}
\hline Data collection tools & $f$ & $\%$ \\
\hline Survey & 64 & 27.58 \\
Log data & 57 & 24.57 \\
Student interviews & 33 & 14.22 \\
Observation & 18 & 7.76 \\
Student opinions & 12 & 5.17 \\
Focus group interview & 11 & 4.74 \\
Scale & 8 & 3.45 \\
Open ended questions & 5 & 2.16 \\
Student grades, pass/fail rates (achievement) & 5 & 2.16 \\
Discussion transcripts & 6 & 2.59 \\
Faculty/instructor interviews & 4 & 1.72 \\
Academic engagement form & 2 & 0.86 \\
Dropout-retention rates & 2 & 0.86 \\
Participation rates to system & 2 & 0.86 \\
Other (Include tools used less than two.) & 3 & 1.29 \\
\hline
\end{tabular}

Surveys $(27.58 \%)$ are the most commonly used data tools to measure student engagement (Table 6). This is followed by log data $(24.57 \%)$ and student interviews (14.22\%). Survey and interviews were found as the most used data collection tool in many studies (Bozkurt et al., 2015; Karatas, Ozcan, Polat, Yilmaz, \& Topuz, 2014; Karatas et al., 2017; Martin et al., 2017) focusing distance education or types of distance education. However log data is not a data source that we are used to see in these studies. For instance only Martin et al. (2017) and Karatas et al. (2017) have mentioned the log data as a data source. It can be said that $\log$ data is gaining popularity and it is considered as a powerful tool in determining engagement in distance education.

\section{Variables Influencing or Related to Student Engagement in Distance Education}

All the variables found as influencing or related to engagement were determined and categorised. Seven principles created by Chickering and Gamson (1987) were used as categories. Six new categories were created in relation to the variables' characteristics. In qualitative studies, the researcher can use a framework that exists in the literature to categorize the codes. If there is no suitable framework, the researcher may construct the categories according to the similarities of the codes, in a logical manner (Yildirim \& Simsek, 2013). In this study, categories were created based on literature, experiences of the researchers and two expert opinions. 
Table 7. Variables influencing student engagement in distance education

\begin{tabular}{|c|c|c|c|}
\hline Categories & Variables $(f)$ & Total $f$ & $\%$ \\
\hline $\begin{array}{l}\text { Active learning } \\
\text { techniques } \\
\text { (Stated in the } \\
\text { seven principles } \\
\text { framework created } \\
\text { by Chickering and } \\
\text { Gamson, 1987). }\end{array}$ & $\begin{array}{l}\text { Diverse assessment techniques (7), Activities based on collaboration (Team-based } \\
\text { learning/competition, peer interaction, Online collaborative learning/ Small group } \\
\text { assignments) (7), Gamification (2), Innovative methods (2), Integrating diverse } \\
\text { multimedia learning objects (2), Problem based learning (2), Augmented learning } \\
\text { (2), Web based technology usage (2), Accessing online resources (1), Active learning } \\
\text { techniques (1), Audience response system (i.e., a clicker) (1), Blended learning with } \\
\text { active learning components (1), Cloud-based reflective learning environment } \\
\text { (1), Digital storytelling (1), Giving previous feedback exemplars (1), Inquiry based } \\
\text { learning (1), Integration of student-generated audio files (1), Participation in video } \\
\text { conferences (1), Promoting lived experience (1), Relevance to learning (1), Role } \\
\text { play activity in second life (1), Task based instruction (1) }\end{array}$ & 40 & 19,70 \\
\hline Media properties & $\begin{array}{l}\text { Social network software/Facebook usage (8), Mobile communication tools (Tablet } \\
\text { PC, mobile phone) usage (6), Using e-learning tools (2), Clicker usage (2), Learning } \\
\text { object usage (2), Web based technology usage (2), Interactive television (1), Web } \\
2.0 \text { tools usage (1), Simulation software (1), Wiki usage (1), Cloud-based learning } \\
\text { environment (1), Interactive software usage (1), Second life (1), Online discussion } \\
\text { (1), Asynchronous collaborative group work (1), Multimedia (1), Considering } \\
\text { learning platform characteristics (1) }\end{array}$ & 33 & 16,26 \\
\hline $\begin{array}{l}\text { Student } \\
\text { characteristics }\end{array}$ & $\begin{array}{l}\text { Achievement (3), Motivation (3), Self-regulation (2), Intention to persist (2), Self- } \\
\text { efficacy (2), Satisfaction (2), Self-esteem (1), Computer self-efficacy (1), Age (1), } \\
\text { Gender (1), Situational interest (1), Student emotions (1), Institutional presence (1), } \\
\text { Internet skills (1), Student cognition (1) }\end{array}$ & 23 & 11,33 \\
\hline Teaching method & $\begin{array}{l}\text { Blended learning (11), E-learning (2), Face to face learning (2), Flipped learning (2), } \\
\text { Synchronous online learning (1), M-learning (1) }\end{array}$ & 19 & 9,36 \\
\hline $\begin{array}{l}\text { Respect for diverse } \\
\text { talents and ways of } \\
\text { learning* }\end{array}$ & $\begin{array}{l}\text { Learner customization (4), Self-regulated learning (2), Scaffolding students (2), } \\
\text { Adaptive learning (1), Open Social Student Modeling (1), Affect sensitive intelligent } \\
\text { system (1), Self-determined learning (1), Student agency (1), Academic standing } \\
\text { (1), Mentoring (1), Motivating students (1), Considering students' characteristics } \\
\text { (1), Knowledge-related identity congruence (1) }\end{array}$ & 18 & 8,87 \\
\hline \multirow{3}{*}{$\begin{array}{l}\text { Student } \\
\text { collaboration- } \\
\text { interaction* }\end{array}$} & $\begin{array}{l}\text { Online collaborative learning (3), Team-based learning (3), Online discussion (2), } \\
\text { Peer interaction ( } 2 \text { ), Peers' befriending motivating, collaborating, and instructing } \\
\text { efforts (1), Small group assignments (1), }\end{array}$ & \multirow[t]{3}{*}{16} & \multirow{3}{*}{7,88} \\
\hline & Online oral communications (1), COI based blended learning design (1), & & \\
\hline & Positive group dynamics (1), Peer assessment (1) & & \\
\hline \multirow[t]{2}{*}{$\begin{array}{l}\text { Student-faculty } \\
\text { interaction* }\end{array}$} & $\begin{array}{l}\text { Instructor's guidance/assistance/support, mentoring students (5), Accessible } \\
\text { instructors (2), Engagement of faculty (1), Tutors' online participation (1), Regular } \\
\text { and appropriate communication (like f2f students) (1), Responsiveness of the } \\
\text { moderator (1), Motivating students (1), }\end{array}$ & \multirow[t]{2}{*}{$\begin{array}{ll}e & \\
r & \\
\text { e } & 13\end{array}$} & \multirow[t]{2}{*}{6,40} \\
\hline & Online oral communications (1) & & \\
\hline Time on task* & $\begin{array}{l}\text { Blended learning (8), Reminders and announcers (2), Flexible flipped learning (1), } \\
\text { Monitoring students (1) }\end{array}$ & 12 & 5,91 \\
\hline $\begin{array}{l}\text { Course/ } \\
\text { content design }\end{array}$ & $\begin{array}{l}\text { Well-designed student/discussion forums (2), Clear expositions (1), Using helpful } \\
\text { course resources (1), Designing digital resources (1), High quality courses that are } \\
\text { specifically designed for online learning (1), Highly structured learning environment } \\
\text { (1), Compulsory course (1), Flexibility (1), Course design (1), Using synchronous } \\
\text { and asynchronous communication together(1), Promote engagement in the first } \\
\text { weeks (1) }\end{array}$ & 12 & 5,91 \\
\hline \multirow{2}{*}{$\begin{array}{l}\text { Innovative } \\
\text { techniques }\end{array}$} & $\begin{array}{l}\text { Gamification (2), Augmented learning (2), Innovative methods (1), Adaptive } \\
\text { learning environment (1), Interactive software usage (1), }\end{array}$ & \multirow[t]{2}{*}{9} & \multirow[t]{2}{*}{4,43} \\
\hline & Innovative methods (1), Digital storytelling (1) & & \\
\hline Prompt feedback* & $\begin{array}{l}\text { Timely feedback (1), Feedback (1), Feedback software usage (1), Personalized } \\
\text { feedback (1) }\end{array}$ & 4 & 1,97 \\
\hline $\begin{array}{l}\text { Instructor } \\
\text { competencies }\end{array}$ & $\begin{array}{l}\text { Instructor's course preparation (1), responsiveness of the moderator (1), } \\
\text { Tutors' e-moderating skills (1) }\end{array}$ & 3 & 1,48 \\
\hline High expectations* & High level questions (1) & 1 & 0,49 \\
\hline
\end{tabular}


Most of the researchers have reached results about using active learning techniques (Table 7). The second variable was determined as media properties. It can be said that the properties of the media are quite important in promoting student engagement. At this point it is necessary to remember the debate between Kozma $(1991 ; 1994)$ and Clark $(1994 ; 1995)$. Contrary to Clark's claim, the prominence of the media was determined in this study. Similarly, Bollgier and Martin (2018) have found that according to students the most valuable component of the online courses is course materials. Besides, engaging with the course materials increases the possibility of retention (Kumar \& Shastry, 2019).

Another important component is student characteristics. In order to promote student engagement in distance education, instructors or instructional designers need to consider student characteristics (Williams, Stafford, Corliss, \& Reilly, 2018). The teaching method used, blended, flipped, adapted etc. is important. Besides, students state in the studies that the course design affects their engagement. The results of the study by Rienties, Lewis, McFarlane, Nguyen and Toetenel (2018) support this statement. They have found that the way instructors design the modules directly predicts students' behaviour in virtual learning enviroments. At this point the importance of instructor competencies becomes clear. Using innovative techniques support student engagement. It is necessary to state that there is a significant effort on determining the effects of social media on engagement. Furthermore all of the principles determined by Chickering and Gamson (1987) are important in order to promote engagement in distance education.

\section{Theories and Frameworks Used to Ground the Studies}

Table 8. Theories and frameworks used to ground the studies

\begin{tabular}{lll}
\hline Theories & $f$ & $\%$ \\
\hline Self-Determination Theory of Motivation & 4 & 2.53 \\
Seven Principles & 4 & 2.53 \\
Original models developed by the researchers & 4 & 2.53 \\
Transactional Distance Theory & 3 & 1.90 \\
Community of inquiry & 2 & 1.27 \\
Community of practice & 2 & 1.27 \\
Sharon Pittaway's engagement framework & 2 & 1.27 \\
Theory of Engagement (Shneiderman et al. 1995). & 2 & 1.27 \\
Other (used less than twice) & 25 & 15.82 \\
Not specified & 110 & 69.62 \\
\hline
\end{tabular}

Three theories/frameworks were used more frequently than others, Self-Determination Theory of Motivation $(2.53 \%)$, Seven Principles $(2.53 \%)$, original models developed by the researchers $(2.53 \%)$. The reason for using Self-Determination Theory of Motivation (Deci \& Ryan, 2004) may be due to it being a theory that tries to make the activities meaningful for the students and so make them participate in the activities (Tan $\&$ Hew, 2016). However, because the seven principles framework was a framework for student engagement, it was expected to be used more. The efforts of the researchers to create new models or frameworks is worthwhile but not enough. Furthermore, majority of the studies (69.62 \%) haven't used any particular theories or frameworks. Many of the theories used in these studies were not directly related to student engagement. The lack of using theories or frameworks was also emphasized in some previous studies (Karatas et al., 2014; Karatas et al., 2017). 


\section{Technologies Used in the Studies}

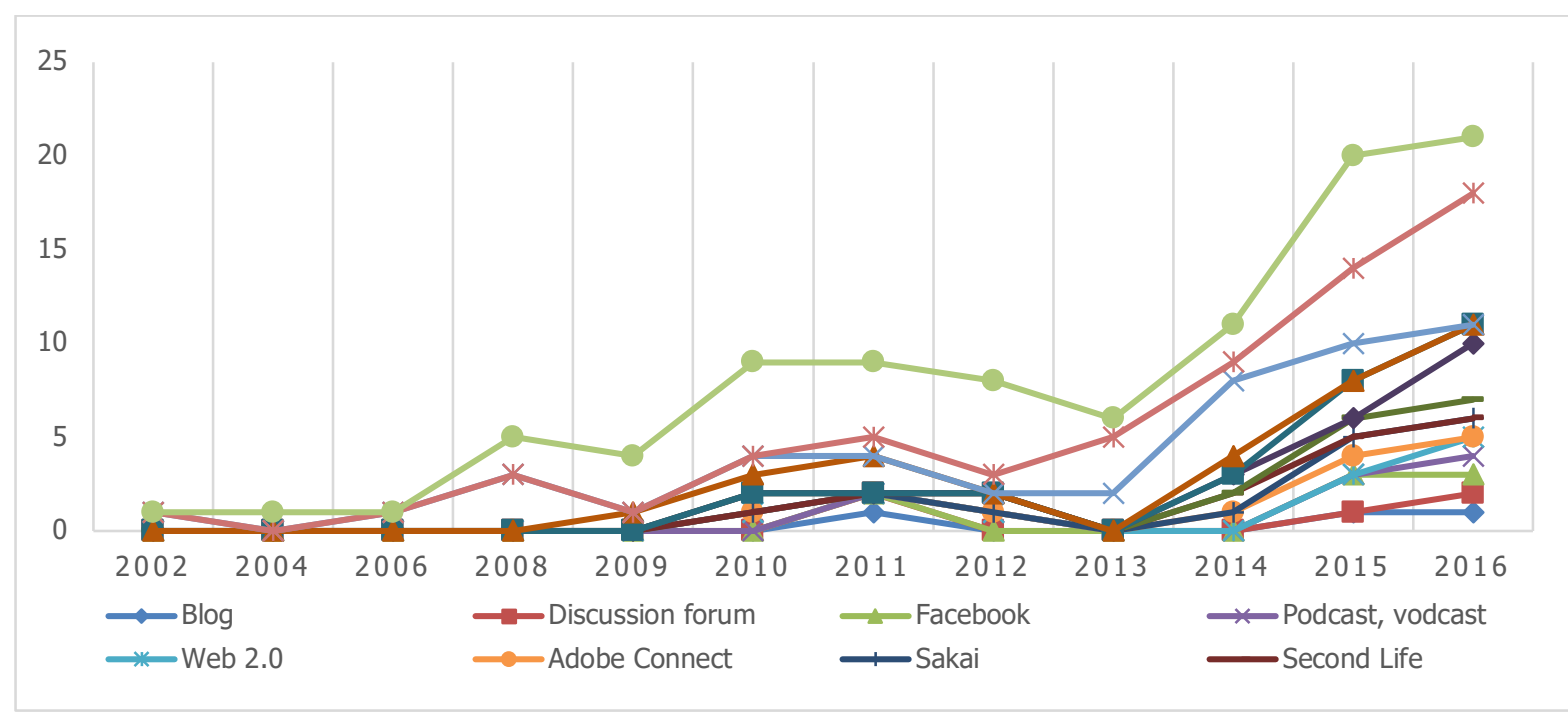

Figure 7. Technologies/media tools used in the studies

Learning management systems (LMS) are used frequently (Blackboard/WebCT $f=32$ and Moodle $\mathrm{f}=17$ ) in the studies (Figure 7). Some researchers $(f=14)$ try to develop original LMSs, websites or software. LMS was also determined as the most used technology in the studies conducted by Karatas et.al. (2017) and Martin et al. (2017). The LMS is followed by many collaborative tools such as wiki, Google docs, MOOCs, blog, discussion forum, Facebook etc. When it is considered promoting student collaboration is an essential component for engagement (see Table 7) it is not surprising that researchers focus on these collaborative tools. Besides, it is beneficial to mention that 33 of the studies haven't stated any technology, and because 43 of the technologies have been stated only once these Technologies haven't been given in the figure.

\section{CONCLUSION}

In line with the literature (Ma et al., 2015) results of this study showed that the efforts on understanding student engagement in distance education have been increasing over the years. This increase is not surprising when it is considered that engagement plays a vital role in promoting student retention, and increasing student retention rates is quite important for educational institutions. As some countries such as the USA, UK, and Australia have many studies on the subject, many countries need to put more effort in order to contribute to the area. Although the majority of studies are expected to be conducted in the field of education, most of them have been conducted in the health sciences. Therefore, it can be said that the researchers in the field of education need to make more efforts in this regard.

Most of the studies focused on issues that refer to the micro perspective (instructional design, interaction and communication in learning communities, and learner characteristics), and the number of studies conducted in macro-level (distance teaching systems and institutions, and theories/models etc.) is not sufficient when compared with micro and meso-level. It can be said that researchers may consider focusing on macro-level topics.

It is hopeful that the number of mixed methods studies is increasing. Mixed method studies are worthwhile in terms of providing deep information. On the other hand, when it is considered that the most commonly used data collection tool in the studies examined is surveys, it may be recommended that developing and using more valid and reliable tools such as scales is needed.

Determining the factors affecting student engagement in distance education was the most important part of this study. All of the articles were examined in terms of variables effecting student engagement and these variables were classified based on the seven principles framework (Chickering \& Gamson, 1987). It was found that all the principles of this framework were important in promoting student engagement in distance 
education. However, six new components need to be considered: media properties, student characteristics, teaching method, course/content design, innovative techniques, and instructor competencies. These new components may be tested with structural equation modeling or multiple regression analysis in future studies.

\section{LIMITATIONS AND RECOMMENDATIONS}

The current study has some limitations. The first limitation is that this study only examined the Web of Science database. Although the most popular journals in the field are included in this database it is still necessary to examine other databases. The second limitation is that some authors are using the words involvement and participation instead of engagement. In this study, only the word "engagement" was considered when searching the database. However, when examining the articles, the studies which were using engagement in abstract but involvement or participation in the body of the article were also included in the study. Future studies may include all these words in searching words.

As it was recommended under the heading conclusions, focusing on the major level issues of distance education such as distance teaching systems and institutions, and theories/models etc. is necessary. Besides, future studies may consider developing more valid and reliable tools to measure and understand the student engagement in distance learning environments.

Using a theoretical base has a vital role in conducting a comprehensive research. However, in this research, it has found that the majority of the studies haven't used any particular theories or frameworks. Accordingly, it is advisible for the future studies to ground the reseaches on a relevant theoretical base.

Finally, for practitioners, in addition to the seven principles of Chickering and Gamson (1987) we recommend considering the six new components media properties, student characteristics, teaching method, course/ content design, innovative techniques, and instructor competencies when constructing education.

\section{BIODATA and CONTACT ADDRESSES of AUTHORS}

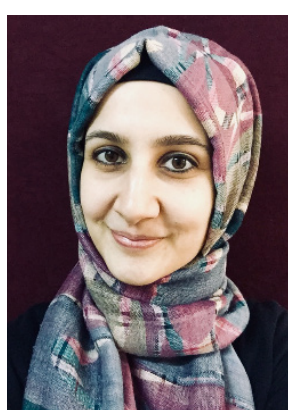

Ayse BAGRIACIK YILMAZ, is a research assistant in Department of Computer Education and Instructional Technologies at Aydin Adnan Menderes University. She has gained her M.A. degree from Gazi University. She has been doing her Ph.D. on distance education since 2015. Her studies focus on distance education, online learning environments, instructional technologies and educational technologies. $\mathrm{He}$ has publications in international and national indexed journals and presented papers in many symposiums. She has taken part in a completed Erasmus+ Strategic Partnership project as a researcher. In 2017, she was a visiting scholar at the University of Nottingham Trent in the UK for seven months.

Ayse BAGRIACIK YILMAZ

Department of Computer Education and Instructional Technologies, Faculty of Education

Address: Aydin Adnan Menderes University, 09000, Aydin, Turkey

Phone: +90 2562142023,

E-mail: ayse.yilmaz@adu.edu.tr 


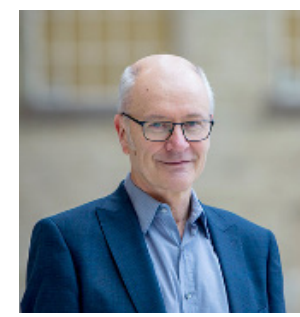

Dr. Phil BANYARD, is Associate Professor in Psychology and is currently Head of Department. Phil Banyard has been with the Nottingham Trent University for over 25 years during which time he has also been a Chief Examiner for GCSE and then A Level Psychology. Prior to joining the University, he did time as a psychiatric nursing assistant, a community worker and a lecturer in further education. Phil Banyard's research activity focuses on education. For the last 15 years he has been a leading member of projects studying the impact of digital technologies in schools. This work attracted grants in excess of $£ 1,000,000$ from government agencies and the European Commission. He continues to publish on this topic. Another area of work has been the development of A-Level Psychology in the school sector and its impact on the character of the subject. Phil Banyard's 30 year involvement with schools examinations facilitates a combination of practice and research. Other research activity includes publications on health information and the promotion of healthy behaviours, and also the benefits of narrative in training programmes.

Phil BANYARD

Psychology, School of Social Sciences

Address: Nottingham Trent University, NG14FQ, Nottingham, UK

Phone: +44 1158485585 ,

E-mail: phil.banyard@ntu.ac.uk

\section{REFERENCES}

Adwan, J. (2016). Dynamic online peer evaluations to improve group assignments in nursing e-learning environment. Nurse Education Today, 41, 67-72. doi:10.1016/j.nedt.2016.03.028

Anadolu University (2017). Retrieved June 04, 2017 from https://www.anadolu.edu.tr/universitemiz/ sayilarla-universitemiz/ogrenci-sayilari/2016-2017-ogrenci-sayilari/haziran-2017

Andrew, L., Ewens, B., Maslin-Prothero, S.. (2015). Enhancing the online learning experience using virtual interactive classrooms. Australian Journal of Advanced Nursing, 32(4), 22. Retrieved June 05, 2017 from http://www.ajan.com.au/Vol32/Issue4/3Andrew.pdf

Armellini, A., \& Aiyegbayo, O. (2010). Learning design and assessment with e-tivities. British Journal of Educational Technology, 41(6), 922-935. doi:10.1111/j.1467-8535.2009.01013.x

Bernat, F., \& Frailing, K. (2015). Perfecting lessons learned for criminal justice online graduate education: Reflection, integration, and application. Journal of Criminal Justice Education, 26(3), 330-353. do i: $10.1080 / 10511253.2015 .1036090$

Bolliger, D. U., \& Halupa, C. (2018). Online student perceptions of engagement, transactional distance, and outcomes. Distance Education, 1-18, 299-316. doi: 10.1080/01587919.2018.1476845

Boston, W. E., Ice, P., \& Gibson, A. M. (2011). Comprehensive assessment of student retention in online learning environments. School of Arts and Humanities. Retrieved June 07, 2017 from https:// digitalcommons.apus.edu/cgi/viewcontent.cgi?article $=1000 \&$ context=facultySAH

Boyle, F., Kwon, J., Ross, C., \&Simpson, O. (2010). Student-student mentoring for retention and engagement in distance education. Open Learning, 25(2), 115-130. doi:10.1080/02680511003787370

Bozkurt, A., Kumtepe, E. G., Kumtepe, A. T., Aydin, I. E., Bozkaya, M., \& Aydin, C. H. (2015). Research trends in Turkish distance education: A content analysis of dissertations, 1986-2014. European Journal of Open, Distance and E-learning, 18(2), 1-21. doi:10.1515/eurodl-2015-0010

Brinton, C. G., Rill, R., Ha, S., Chiang, M., Smith, R., \& Ju, W. (2015). Individualization for education at scale: MIIC design and preliminary evaluation. IEEE Transactions on Learning Technologies, 8(1), 136-148. doi:10.1109/TLT.2014.2370635

Carpenter, S., Reddix, R., \& Martin, D. (2016). Pills, thrills, and pharmacology drills! Strategies to increase student retention in an entry-level nursing pharmacology course. Teaching and Learning in Nursing, 11(4), 179-183. doi:10.1016/j.teln.2016.04.002 
Chae, S. E., \& Shin, J. H. (2016). Tutoring styles that encourage learner satisfaction, academic engagement, and achievement in an online environment. Interactive Learning Environments, 24(6), 1371-1385. doi:10.1080/10494820.2015.1009472

Chen, J., Luo, N., Liu, Y., Liu, L., Zhang, K., \& Kolodziej, J. (2016). A hybrid intelligence-aided approach to affect-sensitive e-learning. Computing, 98(1-2), 215-233. doi:10.1007/s00607-014-0430-9

Chen, P. S. D., Gonyea, R., \& Kuh, G. (2008). Learning at a distance: Engaged or not?. Innovate: Journal of Online Education, 4(3), 3. Retrieved April 10, 2017 from http://nsuworks.nova.edu/cgi/ viewcontent.cgi?article $=1058 \&$ context $=$ innovate

Chickering, A. W., \& Gamson, Z. F. (1987). Seven principles for good practice in undergraduate education. AAHE bulletin, 3, 7. Retrieved February 08, 2017 from http://files.eric.ed.gov/fulltext/ED282491. $\mathrm{pdf}$

Chickering, A. W., \& Ehrmann, S. C. (1996). Implementing the seven principles: Technology as lever. AAHE Bulletin (October), 3-6. Retrieved February 08, 2017 from http://sphweb.bumc.bu.edu/ otlt/teachingLibrary/Technology/seven_principles.pdf

Clark, R. E. (1994). Media will never influence learning. Educational technology research and development, 42(2), 21-29. doi:10.1007/BF02299088

Clark, S. E. (1995). The generation effect and the modeling of associations in memory. Memory \& Cognition, 23(4), 442-455. doi:10.3758/BF03197245

Cochran, J. D., Campbell, S. M., Baker, H. M., \& Leeds, E. M. (2014). The role of student characteristics in predicting retention in online courses. Research in Higher Education, 55(1), 27-48. doi:10.1007/ s11162-013-9305-8

Conway, S. E., Johnson, J. L., \& Ripley, T. L. (2010). Integration of team-based learning strategies into a cardiovascular module. American journal of pharmaceutical education, 74(2), 35. doi:10.5688/ aj740235

Costas, R., \& van Bochove, C. (2012, Sep). On the relationship between author collaboration and impact of scientific publications. Paper presented at 17 th international conference on science and technology indicators, Canada.

Creswell, J. W. (2013). Research design: Qualitative, quantitative, and mixed methods approaches. California: Sage.

Csikszentmihalyi, M. (1997). Finding flow: The psychology of engagement with everyday life. Retrieved January 11, 2017 from http://www.worldcat.org/title/finding-flow-the-psychology-of-engagement-witheveryday-life/oclc/316021272/viewport

Deci, E. L., \& Ryan, R. M. (2004). Handbook of self-determination research. Rochester, NY: University of Rochester Press. Retrieved January 07, 2017 from http://www.worldcat.org/title/handbook-ofself-determination-research/oclc/249185072/viewport

Franklin, J. (1999). Structure and domain-independence in the formal sciences. Studies in History and Philosophy of Sciences, 30(4), 721-723. doi: 10.1016/S0039-3681(99)00022-9

Fukuzawa, S., \& Boyd, C. (2016). Student engagement in a large classroom: using technology to generate a hybridized problem-based learning experience in a large first year undergraduate class. Canadian Journal for the Scholarship of Teaching and Learning, 7(1), 7. doi:10.5206/cjsotl-rcacea.2016.1.7

George-Walker, L. D., \& Keeffe, M. (2010). Self-determined blended learning: a case study of blended learning design. Higher Education Research \& Development, 29(1), 1-13. doi:10.1080/07294360903277380

Goktas, Y., Kucuk, S., Aydemir, M., Telli, E., Arpacik, O., Yildirim, G., \& Reisoglu, I. (2012). Educational technology research trends in Turkey: A content analysis of the 2000-2009 decade. Educational Sciences: Theory and Practice, 12(1), 191-199. Retrieved June 13, 2017 from http://www.kuyeb.

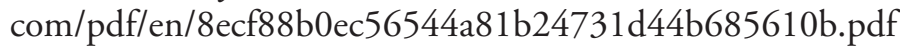


Gregory, S., \& Masters, Y. (2012). Real thinking with virtual hats: A role-playing activity for pre-service teachers in Second Life. Australasian Journal of Educational Technology, 28(3). doi:10.14742/ ajet. 843

Herrington, J., Oliver, R., \& Reeves, T. C. (2003). Patterns of engagement in authentic online learning environments. Australasian Journal of Educational Technology, 19(1). doi:10.14742/ajet.1701

Hew, K. F., Huang, B., Chu, K. W. S., \& Chiu, D. K. (2016). Engaging Asian students through game mechanics: Findings from two experiment studies. Computers \& Education, 92, 221-236. doi:10.1016/j.compedu.2015.10.010

Hung, J. L., \& Zhang, K. (2012). Examining mobile learning trends 2003-2008: A categorical meta-trend analysis using text mining techniques. Journal of Computing in Higher education, 24(1), 1-17. doi:10.1007/s12528-011-9044-9

Hwang, G. J., \& Tsai, C. C. (2011). Research trends in mobile and ubiquitous learning: A review of publications in selected journals from 2001 to 2010. British Journal of Educational Technology, 42(4). doi:10.1111/j.1467-8535.2011.01183.x

Karatas, S., Ozcan, S., Polat, E., Yilmaz, Y., \& Topuz, A. C. (2014). Trends in Distance Education: Theories and Methods. Handbook of Research on Emerging Priorities and Trends in Distance Education: Communication, Pedagogy, and Technology: Communication, Pedagogy, and Technology, 141.

Karatas, S., Bagriacik-Yilmaz, A., Dikmen, C. H., Ermis, U. F., Gurbuz, O. (2017). Interaction in Distance Education Environments: A Trend Analysis. Quarterly Review of Distance Education, 18(1), 63-82.

Kearsley, G., \& Shneiderman, B. (1998). Engagement theory: A framework for technology-based teaching and learning. Educational technology, 38(5), 20-23.

Kilic-Cakmak, E., Kukul, V., Cetin, E., Berikan, B., Kandemir, B., Pamukcu, B. S., Taskin, N., \& Marangoz, M. (2015). 2013 yili egitim teknolojileri arastirmalarinin incelenmesi: AJET, BJET, C\&E, ETRD, ETS ve L\&I dergileri. Egitim Teknolojisi Kuram ve Uygulama, 5(1), 128-160. doi:10.17943/ etku. 17190

Kozma, R. B. (1991). Learning with media. Review of educational research, 61(2), 179-211.

Kozma, R. B. (1994). Will media influence learning? Reframing the debate. Educational technology research and development, 42(2), 7-19. doi:10.1007/BF02299087

Kuh, G. D. (2003). What we're learning about student engagement from NSSE: Benchmarks for effective educational practices. Change: The Magazine of Higher Learning, 35(2), 24-32. doi:10.1080/00091380309604090

Kuh, G. D. (2009). What student affairs professionals need to know about student engagement. Journal of College Student Development, 50(6), 683-706. Retrieved January 12, 2017 from https://eric. ed.gov/?id=EJ868898

Kuiper, A., Solomonides, I., \& Hardy, L. (2015). Time on task in intensive modes of delivery. Distance Education, 36(2), 231-245. doi:10.1080/01587919.2015.1055058

Landis, J. R. \& Koch, G. (1977). The measurement of observer agreement for categorical data. Biometrics, 33, 159-174. doi: $10.2307 / 2529310$

Kumar, S. S., \& Shastry, P. M. (2019). Analysis of Student Engagement and Course Completion in Massive Open Online Courses. In Integrated Intelligent Computing, Communication and Security (pp. 447458). Singapore: Springer.

Lee, L. (2016). Autonomous learning through task-based instruction in fully online language courses. Language Learning \& Technology, 20(2), 81-97. Retrieved June 08, 2017 from http://llt.msu.edu/ issues/june2016/lee.pdf

Ma, J., Han, X., Yang, J., \& Cheng, J. (2015). Examining the necessary condition for engagement in an online learning environment based on learning analytics approach: The role of the instructor. The Internet and Higher Education, 24, 26-34. doi:10.1016/j.iheduc.2014.09.005 
Maisonneuve, H., Chambe, J., Lorenzo, M., \& Pelaccia, T. (2015). How do general practice residents use social networking sites in asynchronous distance learning?. BMC medical education, 15(1), 154. doi:10.1186/s12909-015-0435-x

Martin, F., Ahlgrim-Delzell, L., \& Budhrani, K. (2017). Systematic review of two decades (1995 to 2014) of research on synchronous online learning. American Journal of Distance Education, 31(1), 3-19. doi:10.1080/08923647.2017.1264807

Martin, F. \& Bolliger, D.U. (2018). Engagement matters: Student perceptions on the importance of engagement strategies in the online learning environment. Online Learning 22(1), 205-222. doi:10.24059/olj.v22i1.1092

Matthews, K. E., Andrews, V., \& Adams, P. (2011). Social learning spaces and student engagement. Higher Education Research \& Development, 30(2), 105-120. doi:10.1080/07294360.2010.512629

Mehvar, R. (2010). A participation requirement to engage students in a pharmacokinetics course synchronously taught at a local and distant campus. American journal of pharmaceutical education, 74(7), 118. doi:10.5688/aj7407118

Moore II, E., Utschig, T. T., Haas, K. A., Klein, B., Yoder, P. D., Zhang, Y., \& Hayes, M. H. (2008). Tablet PC technology for the enhancement of synchronous distributed education. IEEE Transactions on Learning Technologies, 1(2), 105-116. doi:10.1109/TLT.2008.19

Neumann, D. L., \& Hood, M. (2009). The effects of using a wiki on student engagement and learning of report writing skills in a university statistics course. Australasian Journal of Educational Technology, 25(3). doi:10.14742/ajet.1141

Northey, G., Bucic, T., Chylinski, M., \& Govind, R. (2015). Increasing studentengagement usingasynchronous learning. Journal of Marketing Education, 37(3), 171-180. doi:10.1177/0273475315589814

NSSE, (2017). About NSSE. Retrieved May 10, 2017 from http://nsse.indiana.edu/html/about.cfm

Park, J. H., Schallert, D. L., Sanders, A. J., Williams, K. M., Seo, E., Yu, L. T., Vogler, J. S., ... \& Knox, M. C. (2015). Does it matter if the teacher is there?: A teacher's contribution to emerging patterns of interactions in online classroom discussions. Computers \& Education, 82, 315-328. doi:10.1016/j. compedu.2014.11.019

Pascarella, E. T., and Terenzini, P. T. (2005). How college affects students: A third decade of research. San Francisco: Jossey-Bass.

Prior, D. D., Mazanov, J., Meacheam, D., Heaslip, G., \& Hanson, J. (2016). Attitude, digital literacy and self efficacy: Flow-on effects for online learning behavior. The Internet and Higher Education, 29, 91-97. doi:10.1016/j.iheduc.2016.01.001

Protsiv, M., Rosales-Klintz, S., Bwanga, F., Zwarenstein, M., \& Atkins, S. (2016). Blended learning across universities in a South-North-South collaboration: a case study. Health research policy and systems, 14(1), 67. doi:10.1186/s12961-016-0136-x

Rienties, B., Lewis, T., McFarlane, R., Nguyen, Q., \& Toetenel, L. (2018). Analytics in online and offline languagelearning environments: the role oflearning design to understand student online engagement. Computer Assisted Language Learning, 31(3), 273-293, doi: 10.1080/09588221.2017.1401548

Shneiderman, B., Alavi, M., Norman, K., \& Borkowski, E. Y. (1995). Windows of opportunity in electronic classrooms. Communications of the ACM, 38(11), 19-24. doi:10.1145/219717.219725

Simpson, O. (2013). Student retention in distance education: are we failing our students?. Open Learning: The Journal of Open, Distance and e-Learning, 28(2), 105-119. doi:10.1080/02680513.2013.847 363

Snodgrass, S. (2011). Wiki activities in blended learning for health professional students: Enhancing critical thinking and clinical reasoning skills. Australasian Journal of Educational Technology, 27(4). doi:10.14742/ajet.938 
Stebbings, S., Bagheri, N., Perrie, K., \& Blyth, P. (2012). Blended learning and curriculum renewal across three medical schools: The rheumatology module at the University of Otago. Australasian Journal of Educational Technology, 28(7). doi:10.14742/ajet.795

Sutherland, L., Howard, S., \& Markauskaite, L. (2010). Professional identity creation: Examining the development of beginning preservice teachers' understanding of their work as teachers. Teaching and teacher education, 26(3), 455-465. doi:10.1016/j.tate.2009.06.006

Tan, M., \& Hew, K. F. (2016). Incorporating meaningful gamification in a blended learning research methods class: Examining student learning, engagement, and affective outcomes. Australasian Journal of Educational Technology, 32(5). doi:10.14742/ajet.2232

Thoms, B., \& Eryilmaz, E. (2014). How media choice affects learner interactions in distance learning classes. Computers \& Education, 75, 112-126. doi:10.1016/j.compedu.2014.02.002

Toven-Lindsey, B., Rhoads, R. A., \& Lozano, J. B. (2015). Virtually unlimited classrooms: Pedagogical practices in massive open online courses. The internet and higher education, 24, 1-12. doi: doi.org/10.1016/j.iheduc.2014.07.001

Tower, M., Walker, R., Wilson, K., Watson, B., \& Tronoff, G. (2015). Engaging, supporting and retaining academic at-risk students in a Bachelor of Nursing: Setting risk markers, interventions and outcomes. The International Journal of the First Year in Higher Education, 6(1), 121. doi:10.5204/ intjfyhe.v6i1.251

Tsai, C. W. (2015). The effect of online co-regulated learning in the implementation of team-based learning on improving students' involvement. Higher Education Research \& Development, 34(6), 12701280. doi:10.1080/07294360.2015.1024631

van Oordt, T., \& Mulder, I. (2016). Implementing basic e-learning tools into an undergraduate taxation curriculum. Meditari Accountancy Research, 24(3), 341-367. doi:10.1108/MEDAR-08-2015-0054

Wanner, R. A., Lewis, L. S., \& Gregorio, D. I. (1981). Research productivity in academia: a comparative study of the sciences, social sciences and humanities. Sociology of Education, 54(4), 238-253. doi: $10.2307 / 2112566$

Wanner, T., \& Palmer, E. (2015). Personalising learning: Exploring student and teacher perceptions about flexible learning and assessment in a flipped university course. Computers \& Education, 88, 354369. doi:10.1016/j.compedu.2015.07.008

Williams, K. M., Stafford, R. E., Corliss, S. B., \& Reilly, E. D. (2018). Examining student characteristics, goals, and engagement in Massive Open Online Courses. Computers \& Education, 126, 433-442, doi: /10.1016/j.compedu.2018.08.014

Wu, W. H., Wu, Y. C. J., Chen, C. Y., Kao, H. Y., Lin, C. H., \& Huang, S. H. (2012). Review of trends from mobile learning studies: A meta-analysis. Computers \& Education, 59(2), 817-827. doi:10.1016/j. compedu.2012.03.016

Yildirim, A., \& Simsek, H. (2013). Sosyal bilimlerde nitel arastirma yontemleri (Qualitative research methods in social sciences). Ankara: Seckin.

Xie, K. (2013). What do the numbers say? The influence of motivation and peer feedback on students' behaviour in online discussions. British Journal of Educational Technology, 44(2), 288-301. doi:10.1111/j.1467-8535.2012.01291.x

Zawacki-Richter, O., Backer, E. M., \& Vogt, S. (2009). Review of distance education research (2000 to 2008): Analysis of research areas, methods, and authorship patterns. The International Review of Research in Open and Distributed Learning, 10(6), 21-50. doi:10.19173/irrodl.v10i6.741

Zawacki-Richter, O., \& von Prummer, C. (2010). Gender and collaboration patterns in distance education research. Open Learning, 25(2), 95-114. doi:10.1080/02680511003787297 